\title{
SEMANTICS AND PHILOSOPHY
}

\section{PHILIP PERFETTI}

St. John's University, New York

"Philosophy is every man's business... it is too important to be left to the experts".

William James

Ethymologically philosophy means "love of wisdom", but if we were to define it, we could call it "the love of", and therefore, "the quest for truth". Truth, wherever it is to be found: whether in a formal principle of reasoning (Logic), in a form of beauty (Aesthetics), in an ideal conduct (Ethics), in a type of government (Politics) or in the ultimate reality of things (Metaphysics).

We all too well know, however, that, generally speaking, there is no easy path to truth. Truth, whatever the field of research, for its intrinsic and essential characteristic of uniqueness, whenever attained, constitutes a conquest. And conquest means struggle. Struggle against all forms of errors, fallacies, deceptions, distortions and falsities.

It goes without saying that language plays an important role in this struggle: the all important role of bringing images, ideas and concepts from the vague, indefinite, transient, somehow aery and nebulous state of thoughts to the more consistent, definite, permanent state of words.

Language, in other words, is a means and therefore it has its worth in the end it serves. It is interesting to note, in this regard, that whenever we pronounce the word "means" our mind goes 
instinctively and instantaneously to that something which the means serves. We can hardly think of a "means" without associating it with the thing it is used for, the "end".

A means alone, in itself and by itself, has no reason to exist. Man would have never dreamt of constructing a train if he had not envisaged the purpose it could serve. No train has ever run which was not meant to transport something. Even a toy train, besides serving the purpose of entertaining a child, transports countless loads in the imaginative mind of its little operator.

And so it is with language. It serves the all useful purpose of conveying our thought to others. Without language, every man, indeed, would be an island. The importance of language being what it is, it goes without saying that the proper usage of it should be a special object of our care and study.

However, important as it is, language is still but a "means". that is to say, it is at the service of something else, which, as we said, happens to be our thought. Thought, so to speak, travels on language as a passenger travels on a train, and, in a manner, that, wherever there is language we expect to find thought. More or less meaningful thought, of course (as the case might be), but thought anyhow.

Now, in centuries of more or less successful attempts to give an answer to the numerous interrogatives of philosophy, there has been, for better or worse, such an accumulation of mental matter (in terms of spoken and, consequently, of written language) between us and the problems themselves, that philosophical skies have grown hazier, perspectives dimmer, and, in many cases, I am afraid, the very sight of the problems has been lost.

If we open a current treatise of philosophy, indeed, it will not take us long to find out that philosophy, as it is, has much wandered off the original path it was meant to tread. I mean, we will have to go a long way before we find such interesting and capital problems as those concerning, for example, "The Existence of God", "The immortality of the Soul", "The Presuppositions of Ultimate Reality", "Knowledge and Existence" "Body-Mind Relation", "Truth and Error" "Good and Evil", "Space and Time", "Reality", "The Entity of Physical Things", "Consciousness", "Value" and alike, clearly, plainly, uncloudedly, simply, uninvolvedly, straightforwardly and, may I add, decidedly met and dealt with.

Now, I do not doubt that discussions such as, for example the following, on "The Theory of Types": 
For all their drastic character the segregatory technique of the theory of types prove insufficient to cure all philosophica! confusions which can be attributed to excessive confidence in grammatical structure as a guide to logical form. A notable instance of such confusion arises in connection with the syntactical properties of frases of the form -so and so. ${ }^{1}$

and others concerning "The Theory of Descriptions as a Metaphisically Neutral Technique of Translations",, or "The Doctrine of Logical Constructions and its Reliance upon the Principle of Reducibility to Acquaintance", 3 may, in the long run, prove relevant in reaching the practical conclusions sought by Bertrand Russell in his "Search for the Ultimate Constifuents of the World", ${ }^{4}$ but the fact is that they do prove alarmingly inadequate in getting our interest.

Perhaps it is because of the nature of the subject, perhaps it is because of the nature of our mind, the fact is that philosophers get often, lengthily, terribly, unforgivably involved in questions of not extremely evident relevance. It seems to me that almosi unconsciously they slip into the futile performance of verbal virtuosities, twists of words, linguistic acrobatisms, which remind me so much of the twists of hands, fumblings, fiddlings, the musicans engage in, for the mere sake of warming themselves up, or of tuning their instruments up, at a concert, before the real performance starts.

Now, it is not that I want to underrate Semantics, Pragmatics, Syntax, Symbolism and the host of related fields of the linguistic family. Problems of Language have a place of long standing in Philosophy. Plato himself dedicated to the subject an entire dialogue (Kratylos). Inquiries as to the role of language in thought were conducted Aristotle, Augustine, Aquinas, Hobbes, Bacon, Descartes, Spinoza, Locke, Berkeley and a host more. 5

1 Max Black, in an overall evaluation of Bertrand Russell's philosophy groups this discussion on the "Theory of Types" and the following ones, which I also am citing, under the comprehensive title: "Search for the Ultimate Constituents of the World". Max Blak, Language and Philosophy, Ithaca (N.Y.), Cornell University Press, 1949, p. 122.

2 lbid. p. 125.

3 lbid. p. 127.

4 lbid. p. 122.

5 Aristotle, Interpretation, CH.1-5; Posterior Analytics, BK.1, CH.10; Soul, BK.11, CH.8. St. Augustine, Confessions, BK.XI, par. 5; BK.XII, par. 32-36 \& par. 41-43; BK.XIII, par. 36; Christian Doctrine, BK.I, CH.13; BK.II, CH.3 \& CH.36. St. Thomas, Summa Theologica, I, Q.XIII, A.I, Ans. and Rep. 3; Q.XXXIV, A.I, Ans. and Rep. 1-3; Q.LXIII, A.8, Rep. 1; Q.CVII, A.1, Rep. 1.2; III, Q.VI, A.6, Rep. 3; Q.LX, A.6, Ans. T. Hobbes, Leviathan, Part I \& Part IV. F. Bacon, Novum Organum, BK.I, Apht. 14. R. Descartes, Rules, XIII; Discourse, Part V. B. Spinoza, Ethics, Part II, Prop. 40, Schol. 1 \& Prop. 47, Schol. J. Locke, Human Understanding, BK.I, CH.l, Sect. 15; BK.II, CH.XVI, Sect. 5-7; CH.XXII, Sect. 3-9 \& CH.XXXII, Sect. 7-8; BK.III, CH.1, Sect. 6 \& CH.III, Sect. 1-5. G. Berkeley, Human Knowledge, Intro., 19, 21-25; Sect. 121-122. 
Problems such as those pertaining, for example, to questions of method, analyses of meaning, definition of determining concepts, consideration of a formalized language to be dealt with in a mathematical fashion, and alike, sure are central to the philosophical pursuit of establishing ever more defined rules of understanding among ourselves. But are these mere linguistic problems going to polarize the attention of the contemporary philosophers, monopolize their best intellectual resources and channel them towards the study of questions which, important as they might be, still are but ancillary to those of the main body of philosophical investigation? Without a properly defined language surely there is not going to be a proper philosophy. But to sacrifice our best energies to the insatiable Baal of semantic perfection, to burn the crop of our philosophical intellects on the altar of endless linguistic polemics, this seems to me an inexcusable waste.

In so doing I think we are acting not more wisely than the progressive-minded citizens of Milocca in one of Pirandello's well known short stories. They (the citizens) badly needed to solve the problem of modernizing the lighting system of their town, and to this end they held regular and heated meetings. But in view of the fact that, year after year, the neighboring towns displayed always new and improved methods of lighting, they never got to agree on which method to adopt. That is why, to this very day, they still are, periodically, deep in the heated discussions, and, at night, still deep in the dark.

And so, to return to the Language problem, we are more than justified in looking for a good, or at least, satisfactory method of defining our words and of confining them to the desidered meaning. But let us not get lost in the search. Of course we should apply our skills towards the construction of ever more perfected means of communication, but let us not forget to board them to reach our destination!

As things stand now, with philosophers engulfed in linguistic disquisitions and subtleties and so much off the main track of real philosophical investigation, it is no wonder that the general public of educated persons is ever more estranging itself from the cause of the science wich Will Durant, in his golden little book, called "the front trench in the siege of truth". ${ }^{6}$

"Follow her (Philosophy) - said Socrates to Crito - and serve her and be of good cheer!" But how could we possibly blame anyone

6 Will Durant, The Story of Philosophy, N.Y., Simon \& Schuster. 1926, p. 2. 
for failing to show any sizable amount of enthusiasm or for failing to be taken with sudden fits of optimism and confidence at the thought of solving such problems as those contemplated by "The Linguistic Analysis of Sceptical Arguments", or by "The Extension of the Analysis to the Logical Relations between Vague Symbols", or by "The Immediate Inference not Involving Obversion which Can Be Represented as Valid Inferences in the Functional Calculus of First Order"?

Certainly, these and consanguineous problems demand our vigilant attention, but let us not call on the general mobilization of our best intellects to find out whether "Vagueness is Subjective" or "The Probability Interpretation of Inductive Arguments is a Solution of the Problem of Induction". Let us not wake up the town to tell the people that "today is Monday is true - today is Monday", or that "London is a city is true - London is a city".

If we can go placidly to bed, every night, and even sleep, while fully aware of the fact that philosophers have not yet given an answer to such questions as: "Is the world divided into mind and matter? Is mind subject to matter, or is it possessed of independent powers? Has the universe any unity or purpose? Is it envolving towards some goal? Are there really laws of nature, or do we believe in them only because of our innate love of order? Is man what he seems to the astronomer, a tiny lump of impure carbon and water impotently crawling on a small and unimportant planet? Or is he what he appears to Hamlet? Is he perhaps both at once? Is there a way of living that is noble and another that is base, or are all ways of living merely futile?", 7 why should we, on the other hand, be thrown off our balance, run ourselves out into vasomotor deran gements or perhaps display ancient Norsemen warior-like battle frenzy, at the simple thought that, maybe, "The Standard of Justification can be profitably employed by Critics of Induction" or that "The Tractatus of Wittgenstein may be Self-Contradictory, or that "a Definition of the Consistency Profile has been successfully worked out"?

Philosophy, in and of itself and to start with, is not an easy subject. We have had, to this effect, old complaints

... the philosopher, setting down with thorny arguments the bare rule, is so hard of utterance and so misty to be con ceived, that one that has no other guide but him (to virtue)

7 Bertrand Russell, A History of Western Philosophy, New York, Simon \& Schuster, 1945, p. viii. 
shall wade in him till he be old before he shall find sufficient cause to be honest. For his knowledge standeth so upon the abstract and general that happy is the man who may understand him, and more happy that can apply what he doth understand..."

and new ones

... what I found in proper philosophy was an abstract intellectualism that led me nowhere and contributed nothing to my understanding of human nature or the world about me. It is a realm of metaphysical systems that seem at distant removes from actuality.

and yet, paraphrasing an Italian adage which says "Ne uccide piu" la gola che la spada" (more are killed by gluttony than by sword), I think we could say: more people are kept away from Philosophy because of the linguistic zeal of its champions than because of the abstruseness of the subject itself.

In a beautiful day of spring, when the sun shines bright and all gods seem to be smiling, when the potentialities of nature seem to be all in act, when Heaven and Earth seem to have fulfilled all their promises, who does not feel a poet at heart? Similarly, at the hour of doom, when misfortune strikes and the world seems to grow deaf to our cries, who does not ask "Why?"

Who, at one stage or another of his life has not tried to understand certain features of the world he lives in, or why he lives in it, or why certain peoples hold certain principles of morality to be right and others do not?

Who, in one word, has never asked a question? (Perhaps here we are tempted to say - he who never was a child).

The fact is that we are all born-philosophers in as much as Philosophy is a way of dealing with questions as well as an attempt to solve certain basic problems of universal interest.

Philosophy is the study of Being, of the Reality in which we live. It is not something apart from life, it is life itself under the microscope of a stringent logic.

No one can live without knowing, thinking, judging, in other words, without plilosophizing. And I do not mean to saythat we

8 Sir Philip Sidney, An Apology for Pootry, London, Nelson, 1965, pp. 106-107, (original tisle of the work: Dofense of Poesy, first published in 1595).

9 Philip Freund, The Art of Reading the Novel, New York, Collier, 1965, p. 18. 
should all be Kants or Leibnitzes or Spinozas, just as we can not all be Shakespeares, Alighieris or Shelleys. However, in view of the fact that we are talking, here, of two subjects, namely Poetry and Philosophy, which, as we said, find a natural, responsive chord in human hearts, why should not mankind, as a whole, enjoy and therefore appreciate the works of philosophy just as it enjoys and appreciates the works of poetry?

Of course, acquiescing to the situation and, perhaps, recalling that even in the times of its glorious origins there was someone who portrayed Socrates as an idle rider of clouds or Thales as falling, feet and all, in a hole, while sticking his nose to the stars, we could easily say: "Well, this seems to be the lot of Philosophy!"

However, I maintain that this is needlessly so.

If philosophers could devote themsleves a little more to the study and discussion of the genuine questions that really interest people, if they could drop a little of the linguistic animosity they have among themselves, in favor of a more genuine concern for the investigation of the problems that more deeply and longer have pressed mankind, if, in one word, they could give us again the pleasure that Leonardo called "the joy of undestanding", then, I think, the thinking and, much too often, suffering humanity would, once more, join forces with the daring host of practicing philosophers in a communion of intent and attempt. I mean, if Philosophy could relive the great Era of Platonic discussions, alternately earthy and sublime, about the problems of thought and action, of life and death, of man both as social creature and as a participant in eternity, if the true flavor of those epic debates could be recaptured, if, to sum it up, human imagination could be set afire again in its everlasting pursuit of lasting happiness and wisdom, then, I think, once again we would turn to Philosophy not only for answers but for stimulation and inspiration as well, not only for consolation but for enlightenment and guidance as well, on the road to Truth, the rcad that once found, for the Oneness of Truth itself, can not but lead to the One Who is the Way, the Light, the Truth itself. 